\title{
Emergence of the International Threat of Space Weaponization and Militarization: Harmonizing International Community for Safety and Security of Space
}

\author{
Abbas Sheer, Li Shouping* \\ School of Law, Beijing Institute of Technology (BIT), Beijing, 100081 China \\ Email: sher_prosecutor@yahoo.com, lishouping@bit.edu.cn
}

\begin{abstract}
Space Weaponization and Militarization is a mounting legal issue to the world peace. Selfprotective in its first epochs, the practice of space for military drives has now become aggressive. The notion of militarized space has been changed by that of "weaponized" outer space. The international law in space only stringently forbids placing munitions of mass destruction into orbit. So it is imperative to make such stringent laws, which could easily prevent occurrence of conflicts and tension amongst subjects involving outer space and halt this growing threat of world weaponization. Different nations are trying to put weapons into space and are trying to destroy the beauty of space. The evolution in military possessions in the outer space, Ballistic Missile Defense (BMD) system, Antimissile Laser Weapons (AMW), antisatellite weapons, surveillance, and intelligence capabilities is a question mark for international community. This article provides a detailed overview of the emerging technologies will have serious implications. This paper focuses on the International community to realize the stringent international legislation to prevent the emerging apprehension regarding space weaponization and highlights defect in national and international legislation. The legislative authorities other than United Nations organizations are appropriate for some attendant concerns about military utilization, orbital debris, environmental protection and impact on space tourism have not been covered completely by treaties. It is intended that establishing a uniformity legislative assembly and space court with the enforcement competency at international level to settle disputes of international responsibilities. Thus, this paper suggests international cooperation development on space demilitarization and protection of citizenry of countries regardless the process of using local remedies at the national level. All this process makes more attention to ensure the protection and reassurance of the outer space in the large interest of humanity.
\end{abstract}

Keywords: Space weaponization and militarization, sustainability of space, national and international legislation.

\section{Introduction}

The 21th century is eyewitness of some extraordinary challenges which embrace outdated and nontraditional sides of safety ${ }^{1}$. The innovation in the space technology has forced the states and its representatives to design some mechanism where the all spheres of safety could sufficiently be addressed. The land, the sea, and airspace have attained strategic worth. The twofold use of space technology marks it more worthwhile. U.S. President stated, Space is a war-fighting domain just like the land, air, and the sea. We might have to develop space forced. We have the Air Force; we would have the space force. We have the Army, the Navy. ${ }^{2}$ Thus, this has transported new discussion among the space actors. Space actors have been using their technology for the intelligence collecting and communication dedications. The countries like China, France, Germany, Italy, Israel, Spain, and the UK have used their military space assets for communications and imaging purposes. Hence, it is not a first-hand impression.

\footnotetext{
* Corresponding author

${ }^{1}$ Michael O' Hanlon, Technology Change and the Future Warfare, Manas Publications, New Delhi, 2005, p. 1.

${ }^{2}$ Sandra Erwin, Defense official: Trump is serious about creating a space force, Space News (15 March, 2018).

http://spacenews.com/defense-official-trumpis-serious-about-creating-a-space-force/.
} 
The satellites which might be plotted to turn as arms and extinguish or inactivate the space assets of the opponent country.

Space law as the governing law of space activities ${ }^{3}$ includes a variety of international provisions and rules, which encounter continuing developments of exploration activities in practice. As more exploration and discoveries increase, notable challenges, which could be in conflict with international treaties, will be born. Therefore, this is imperative to investigate various deficiencies in treaties of space law concerning current challenges by considering new technological developments and aims to provide solutions of tackling them particularly relevant to the issue of militarization and its aftermaths.

We are however facing a new situation where research and development have already begun in the space weapons program for the purpose of anti-ballistic missile and anti-satellite warfare. Outer space has thus become an arena for potential confrontation between the Great Powers, instead of remaining mutual culture of manhood and of serving as a sphere for broad international cooperation in scientific and technological matters for the common benefit of mankind.

By its expansion, subsequent assassination of elevated aircraft similar to the U-2, search for safer observations moved more to air. USA and Soviet Union made early efforts to control the space environment. Both these countries arranged experiments and exercises to occupy the space sphere with conventional and nuclear weapons like Anti Satellite Weapon (ASAT) and also the same experiment by new space power China in $2007^{4}$. Thus, Chinese test was a game changer ${ }^{5}$ which compelled great powers to again think about modernizing their space programs. It compelled the U.S. Air Force and Pentagon officials to take effective countermeasures to secure their space assets against aggressors' threat. ${ }^{6}$

So, the military attack through space were practiced in decade of 1960 and still growing into weaponization of the outer space with real deployment of various weapons especially by leading space faring countries. Actually the vision of placing weapons in space started in $20^{\text {th }}$ century came through science fictions, stories and movies, but it transformed into until the World War-II as well as cold war. Firstly, in space most of military movements were undertaken in outer space by Russian military by launching SPUTNIK. This was actually the dawn of space era. Now space is an operational location for military spacecraft or a momentary or temporary transportation source for fatal weapons such as ballistic missiles. Overwhelming majority of the professional and experts express their anxiety for deployment of various weapons in the space will consequently lead to destabilization of the tactical situation between the great powers and weaker states and which has caused as an arms race. This arms race has threatened the entire security of the weaker and fragile nations.

By the end of the 1960s, the powerful nations, USA and Soviet Union often deployed spy satellites to watch the enemy army and its movement. Detective satellites were and continued to be used to observe defeating military possessions in line with weapons regulations treaties, which were, endorsed amongst two superpowers. Use of detective satellite in the way to signified in treaties as national procedural ways of confirmation. Both of the superpowers US and USSR established ballistic missiles to make use of nuclear weapons transverse to unlimited distances ${ }^{7}$. With industrialization of rocket sciences, the collection of quantified missiles increased and at the sometime large-scale ballistic missiles were developed, which may target any position at globe within allocated time counted in seconds than minutes. These ballistic missiles are normally terrified in sub orbit flight. The application of space militarization recently using Global Positioning System (GPS), US military named it as Navigation Signal Timing and Ranging Global Position System (NAVSTAR GPS). This system generally employed to determine a specific location and providing an exact time to attack approximately everywhere on earth. This system contains an International Circular Orbit (ICO) of a satellite group of nearly twenty-

${ }^{3}$ (UNOOSA) United Nations Office for Outer Space Affairs, Space Law.

http://www.unoosa.org/oosa/en/ourwork/spacela w/treaties.html.

${ }^{4}$ Weeden, Brian. 2007 Chinese Anti-Satellite Test Fact Sheet," Secure World Foundation, Updated November 23,

2010, http://swfound.org/media/9550/chinese_asat_fact_sheet_updated_2012.pdf online.

5 For a complete text of the speech proposing the Strategic Defense Initiative,

http://www.pierretristam.com/Bobst/Library/wf-241html.

6 Michael Sirak, Air force leadership: Chinese ASAT marked turning point: space No longer sanctuary, Defense

Dail. (February 12, 2007).

${ }^{7}$ H. York, Nuclear Deterrence and the Military Uses of Space, (F. Long, D. Hafner and J. Boutwell, eds., Weapons and Space, 1999), 17. 
four (24) satellites; these satellites have Nuclear Detonation Detectors (NDD). The United States Department of Defense (USDD) controls The GPS, which can be used by anyone.

So for as, codification of law against the weaponization and use of force is concerned, international community and establishments have made a little effort. There are only two most important treaties which regularize the weaponization and militarization through space, $1^{\text {st }}$ one is outer space treaty and $2^{\text {nd }}$ is space preservation treaty. The outer space treaty was initiated prohibiting the parties "placing of nuclear weapons or any other weapons of mass destruction in orbit of earth, installing them on the moon or any other celestial body, or to otherwise station them in outer space".

The bigger powers like US, Soviet Union, and UK signed the treaty and initiated it into practice on $10^{\text {th }}$ of October 1967. Till the April 27, 2016, 104 countries have endorsed that treaty, and additionally 25 countries have also signed the Outer Space Treaty ${ }^{8}$. The second treaty, which deals with "The Space Preservation Treaty", proposed by United Nation's General Assembly in the form of resolution in contradiction of all type of space weapons. In UN General Assembly the US always voted against almost every provision.

\subsection{What Is Outer Space?}

The outer Space Treaty (1967) is the first effort leading different activities of countries using outer space $^{9}$, which is the first cornerstone of global outer space law and is the basic source of law regulating outer space. In spite of its significance, the makers of the Outer Space Treaty did not give into the Treaty a definition of outer space ${ }^{10}$. Neither the Outer Space Treaty nor other provision of international law defined outer space.

But in general following are some definitions:

a) Generally anything, which is beyond earth's atmosphere, is outer space. There is no existence of air scattering light, consequently whatever we see looking upward at night in sky that is black desolation glittery with planets, stars, and other interplanetary matter.

b) It's significant to comprehend though, that "space" actually comprise everything within the atmosphere of earth as well as all of the water and land on the surface of earth.

There is no clear difference between weaponization and militarization of space. But even then the scholars of international law make some difference in these two terms, which is as follows:

c) "Space weapon" is neither defined in any international treaty nor in any international customary law, nor any domestic law. But treaty and customary law do provide some guidance on the legality of weaponization, no comprehensive definition of "space weapon" is provided.

d) The most difficulty in describing definition of 'Space Weapon' is that there are various systems in space planned for peaceful commitments having the capability to abolish or restrict other objects or being part in the space or in environment of the earth.

As for example, NASA leaped its ever first independent robotic spacecraft, named as DART ${ }^{11}$. Now this DART is being employed as the foundation for futuristic ventures similar to robotic transportation of consignments for space aircrafts and automatic docking maintenance of spacecraft in the orbit. Actually DART works as steering for satellites and also works as anti-satellite weapons.

The relevant literature is rich with proposed definitions of "space weapon". Government of Canada defined Space Weapon as: "Any device designed or modified to inflict physical or operational damage to an object in space through the projection of mass or energy"12. So unless otherwise provided, the other definition of space weapon is as under:

"Any device, whether based on earth, in outer space, or in any other location, designed to cause physical or operational harm to any object in outer space through the projection of mass, the

\footnotetext{
${ }^{8}$ UNCOPUOS $59^{\text {th }}$ session Vienna, 8-17 June 2016, Report of the LSC $55^{\text {th }}$ session, held in Vienna from 4-15 April 2016.

${ }^{9}$ Treaty on Principles Governing the Activities of States in the Exploration and Use of Outer Space art .3.

${ }^{10}$ ibid

11 "NASA DART," accessed April 25, 2011, www.nasa.gov/dart/main/index.html.

${ }^{12}$ Henry L. Stimson, Is the Weaponization of Space Inevitable? www.stimson.com, last accessed on December 5, 2011.
} 
projection of energy, or through direct physical contact; or, any device based in outer space designed or modified to cause physical or operational harm to targets on the Earth through the projection of mass, the projection of energy, or through direct physical contact."

Space-based system, which provides significant support to the military, is generally called Militarization of space. Such support includes intelligence, surveillance, mapping, charting, communications, navigation, missile warning, and environmental data. It is the placement of military technology in outer space. Now actually there are two key aspects for the questions relating to legitimacy of militarization. On one side there is the straightforward positioning and use of various equipment used for military purposes in space. The other side is approximately all other activities in space have military impact. Some of the technologies such like launching vehicles guidance and operations system has dual uses; positive and negative both, civil as well as military use. Satellite technologies also have the same use. Radar system, which is also called remote sensing, can also be used for both, intelligence and climatic data. GNSS/GPS system may be used for directly bombs and cruise missiles ${ }^{13}$. Telecommunication satellites are also used for both civilian and military messages. Other satellites may monitor and intercept telecommunications traffic. Solar power satellites can be used to fuel space-based lasers and can cause havoc.

Though, the presence of space law might assist to restrain the usage of space for military determinations, consequently avoiding its destructive usage ${ }^{14}$. Space militarization is wider term than space weaponization. The militarization of space does not necessarily entail its weaponization ${ }^{15}$.So, a very little effort is made towards distinguishing these two terms but even then a difference is there.

\subsection{International Law to Control Space Weaponization and Militarization}

Space law is considered one of new specialized areas of regulations. It is also imagined that initiation of space law overlapped with launch of ever first satellite during 1957 in the orbit. But recent discussions and other legal research studies relating to prospects for establishment of rules controlling human accomplishments in the outer space appeared greatly prior to this time. Outer space law has only been in existence since the mid-20th century ${ }^{16}$. But issues presented by the weaponization of outer space are comparatively recent.

An understanding of the current law is critical to any meaningful policy discussion on the weaponization of outer space. There are different sources, which govern the law regarding weaponization of outer space like: International Treaties, International Customary Law, Domestic Statutory Law, and Domestic Constitutional Law. Declarations of the UN General Assembly and some other UN entities also contribute to our current understanding of the law governing the weaponization of outer space. Having clarified basic definitional components of this discussion, now we see whether we have enough internationalized law to control weaponization and militarization of the space. Whether it is legal to deploy space weapons? If as so, then what type of weapons may be legally deployed? Are there any legal limitations on the scope of deployment? Are there any secondary legal considerations? And to get reply about these questions we shall have to look towards international and domestic legislation, which deals the weaponization and militarization of space, and main legislation towards this end is as follows:
a. Outer Space Treaty (1967)
b. Limited test ban treaty (1963)
c. Environmental Modification Convention (1978)
d. Some domestic legislations
e. United States Constitution
f. The UN charter \& Principles of International Law
g. Outer Space Registration Convention of (1974)
h. The Moon Agreement (1979)

\footnotetext{
${ }^{13}$ P.B. Larsen Issues Relating to the Civilian and Military Uses of GNSS, (2001), 17.

${ }^{14}$ Cf. P.C. Jessup The Reality of International Law, (1940), 18.

${ }^{15}$ Robert A. Ramey, Armed Conflict on the Final Frontier: The Law of War in Space, (2000), 554.

${ }^{16}$ Robert A. Ramey, Armed Conflict on the Final Frontier: The Law of War in Space, (2000), 283.
} 


\section{Historical Development and Codification of Laws about Weaponization $\&$ Militarization of Space}

\subsection{Early History before the Second World War}

Space law, similar to other divisions of public as well as international law, has been originated with the need to initiate various rules related to governance of relations among international organizations and community of various states. In this perspective wide-ranging areas on sea, land, air in addition to some modern subjects, like humanitarian, are the areas, which are covered by greater federations of law and treaty. Although the science and human mind turned their attentiveness to space insidious earth, and outer space, as there was no lawful dimension to that sphere. It happened with the emergence of advanced technology, especially the progress of rocket technology from theoretic establishment to its ever first usage as war mechanism during second world war, as the rapid development in technology particularly rocket scene seek for the regulation of space laws appeared on for the world's interest drew the attention of lawyers, academic, government officials and then by military as well. Among the different school of thoughts, it was that there should be a series of zones above the territory of a state like the law of the sea, with freedom of flight in the uppermost zone, but these were considering only matters of air space and not space, as we now know it. The eventual result was endorsed in article-1of Paris convention of 1919 of the "complete and exclusive sovereignty" of a state over its superjacent air space. This principle, which got the status of dogma, soon, was reaffirmed at Chicago in $1944^{17}$. However, the Chicago Convention does not solve the issues of space flight or of regulating the use and exploration of space.

The debate on outer space as a region where rules of law would be required on immediacy after the Second World War. However, the first harbingers were much earlier ${ }^{18}$. In 1910, Emile Laude observed that there was dire need for law other than that needed to cope with 'locomotion' in the layer of 'breathable air .The ideas of 'space law' prior to the Second World War is Russian; E. Korovin presented a paper, later published in France, on "conquest of stratosphere and international law" in conference at air law held in Leningrad in $1933^{19}$. There Korovin rehearsed the arguments in favor of state sovereignty over air-space which had been put forward before the First World War and acknowledged that some argued for a 'free zone' above and beyond state sovereignty, but, on grounds of safety and military security, he came down in favor of unlimited state sovereignty ${ }^{20}$. There is nothing but war for progress in technology. Modern rocketry begins with the experiments of Konstantin Tsiolkovski, Robert H. Goddard, Hermnn Oberth and others in the early years of the twentieth century $^{21}$. Soon after Second World War the German diminutive scientist team of rocket launched their project V-II, which was transported to US with the objective to carry on their workings and research activities, this was the foundation stone for the agenda of space rocket. After the world war, USSR also qualified to be accessible for V-II technology. On the other hand, this era became speediest in the development of space technologies in the region.

US started to create their policy to deal outer space to defend legitimacy of satellite communication. That attention with regard to satellite authority over flights emerged most significant soon after the launch of "Sputnik" in 1957, first human made satellite by USSR. It was further noted that in this era various other concepts relevant to space activities also began to appear in the 1940s. That the Moon is "the common heritage of mankind" indicated by Council of the British Interplanetary Society in $1949^{22}$. Since then various international associations and bodies came on a scene for their opinion, sentiments and suggestions as to what law might or should be in case of outer space. Now it is time to see how this

\footnotetext{
${ }_{17}$ Convention on International Civil Aviation, Chicago, 1944.

${ }^{18}$ What follows relies on Jenks, 97-179 and S.E. Doyle, Origins of International Space Law and the International Institute of Space Law of the International Astronautical. Federation (San Diego: Univelt, 2002) and his 'Concepts of Space Law before Sputnik' (1997), 40.

${ }^{19}$ E. Korovin, La Conquéte de la Stratosphere et le Droit International, (Rev. Gen. de Droit Int.,1934) ,41.

20 W. Ley, Rockets, Men and Missiles in Space, (New York: Signet, 1969), 77.

${ }^{21}$ W. Ley, Rockets, Missiles and Space Travel, (New York: Viking Press, 1958),56.

${ }^{22}$ R.A. Smith, Correspondence: Man and his Mark, (Paris: Presses Universities de France, 1949) ,55.
} 
concept of weaponization and militarization of space emerged post Second World War. International organizations, academic and research institutions, space law institutions and governments played their vital role in developing this law of space.

It is necessary over here to mention these international organizations and institutions that contributed toward the progress of law related to space. Many international space law institutions emerged before the Second World War but most important from them are the International Institute of Space Law (IISL), International Academy of Astronautics (IAA), International Law Association and International Astronautical Federation (IAF). With the emergence of IAF, that was a big development in 1950. Although not many papers were directed to questions of law at its early congresses. Numerous academic institutions and international groups have bestowed enough towards the development of space law. In the remaining world the study of space law has developed, sometimes through institutes as mentioned above, and sometimes through cooperation between local academic and local practicing lawyers.

\subsection{History after the Second World War}

Generally, the word "Space Law" is used to refer national and international regulations prevailing manmade activities carried out in outer space. The main objective of this law is to determine legal situations that permit to achieve mutual interest and goal relating to investigation and usage of outer space. Similarly, it also targets to prevent emerging conflicts and clashes among the matters involving outer space activities. Space programs launched particularly by USSR and US after World War-II stimulated historical development in space in the form of weaponization and militarization, which ultimately produced the progress in Space Law. Historical developments after the World War Second can be categorized in the following way.

\subsection{Cold War Era}

After the World War-II from the start of space age, the space race was first switched by the USSR on launching Sputnik-I into the space. ${ }^{23}$ The former USSR and US launched and augmented different activities, which were military based rather than scientific or civilian ${ }^{24}$. During the decades of 1950s-60s, the capacity and superiority of military enhanced rapidly in space technologies. Owing to this strong nervousness between both these super powers in 1967, the treaty on outer space (OST) came into existence. It is pertinent to mention over here that General Assembly of UN quickly responded on November 14, 1957 with regard to the start of utilizing the outer space in Resolution-1148 (XII) that pushed the desire to utilize outer space only for the purpose of peaceful activities. Furthermore, it is to be renowned that the conference on demilitarization by UN has been discussing since 1981 on plan of preventing military competition in outer space, finally reaching on treaty for regulating the military activities in space.

Though, these types of treaties only prohibit placing mass destructive weapons in space, but these treaties don't prevent different countries on placement of some other weapons in the space. The Security in space, which the USA, as also China, each in their own way entitlements to desire to uphold, is also an importance of France and Europe. China, like India and Japan, has been dialog for a long time in favor of disarmament in space. A possible reading of the technological demonstration of January 2007 is that it is endeavoring to influence the Western powers by a demonstration of power superficially opposing to its professed intentions. Thus, several states questioned on faults of these treaties, which are not enough to safeguard space as mutual legacy for humankind. So as to discuss this issue, the UN general assembly concluded to draft on demilitarization approving debates to halt armed race in space to be held with accordance to outer space treaty.

The Conference on Disarmament (CD) created a committee (ad hoc based) to explore and investigate matters related to Prevention of an Arms Race in Outer Space (PAROS), as space based nuclear system,

\footnotetext{
${ }^{23}$ A Brief History of Space Age, http://www. gmupolicy.net/space/short course/1b. \%20Launius\%2020A\%20Brief\%20History\% 20of\%20the\%20Space\%20Age.pdf.

${ }^{24}$ P. Podvig, Russian Military Space Capabilities, (2002), 24.
} 
protecting satellites legally, and other related procedures. ${ }^{25}{ }^{26}{ }_{-}{ }^{27}$ The US continuously denied negotiating PAROS in the CD, keeping progress in largest missile defense program and taking technical advantages in the field of space militarization. So on $1^{\text {st }}$ November 1999, UN resolutions "PAROS" were passed the General Assembly by votes of 138-0 (with 2 absentees), and these two absentees were Israel and USA. The U.S. bombarded down a crippled U.S. spy satellite by means of a sea-based missile defense skill ${ }^{28}$. Though the U.S. announced that this action was only to evade the community protection threat from satellite colliding to Earth. Thus, at the end of 2008, Washington and Beijing seemed to be in the direction of a new-fangled Cold War.

\subsection{Current Situation}

Commercialization of outer space has gained the trends and National Defense Industrial Association (NDIA) envisages by the year 2010, 1700 portable satellites that will be functioning in Earth's range and beyond this 75 percent would be owned by private sector companies. Additionally, in accordance to NDIA transnational companies would possess major space weapons. It was also estimated by 2012, more than 85 percent of satellite communications and almost 25 percent distant sensors satellites would be privately owned to multinational companies and this might be go beyond strict administrative controls ${ }^{29}$.

Furthermore, the business expansion and admittance to distant detecting satellites technologies have reached in current years. Some other nations are also increasing privately owned space technologies and civil satellites descriptions service is attracting ever more availability at commercial markets globally ${ }^{30}$. Alternative trends in the manufacturing of missile based technologies prerequisite initiation of satellite, particularly in emerging nations, like Pakistan, Brazil, Iran and North Korea. In such a way, the enhanced dependence by military activities on commercial based satellites caused different policies reactions from major space advancing countries.

The significance of outer space for United States was obviously confirmed in recent Afghanistan and Iraq war. Almost fifty (50) satellites were supporting United States military activities, and delivering telecommunication linkages for forces on ground, reconnaissance data, ships at sea and aircrafts flights etc. confronted with supposed issues, the United States has more focus on challenges to control space, most likely by means of employing invasive capability which would be able to make certain unhindered make use of their space assets ${ }^{31}$.

It is very interesting that in UN, the resolution approved by General Assembly on December 17, 2004 on PAROS was accepted without any vote against it (4 countries withdrawn, including US and Israel). It reveals that the United States previously voted against almost the same draft, the aim was peaceful use of space and to stop military competition in outers pace to withhold different activities dissimilar to this purposes and appropriate existence of treaties in this interest keeping peace and safety internationally.

\subsection{Artificial Intelligence (AI)}

The other advanced technology which todays raise current news uses a dense combination of mathematics, computer science and other related sciences. Although AI will be extremely beneficial at

${ }^{25}$ Reaching Critical Will's Guide to Conference of Disarmament, 2011.

http://www.reachingcriticalwill.org/political/cd/cdbook2011.pdf. (Accessed 20 February 2018).

${ }^{26}$ E. Karen, House, United States public delegate to the 63rd session of the united nations general assembly, delivered in the debate on outer space (disarmament aspects) of the general assembly's first committee, in: Arms Control Update, U.S. Delegation to the Conference on Disarmament, Geneva, October 20, 2008 available at: http://geneva.usmission.gov/CD/updates/ 1020OuterSpace.html.

${ }^{27}$ For further details, http://www.reachingcriticalwill.org/political/cd/speeches 02/chiruswp_062702cd.htm,.

${ }^{28}$ Victoria Samson, CDI Analysis: Shooting Down USA 193, World Security Institute, Feburary 27, 2008.

http://www.worldsecurityinstitue.org/ showarticles.vfm?id¹/4265.

${ }^{29}$ H. York, Nuclear Deterrence and the Military Uses of Space, (University of Cologne press,1999) 17.

${ }^{30}$ M. Woods, Satellites Provide Vital Reconnaissance, Communications to War Effort, (University of Cologne press, 2005), 44.

${ }^{31}$ J. Wolf, US Eyes Space as Possible Battleground, (Paris: Presses Universities de France, 2005), 47. 
accomplishing its tasks but it is not without danger when it adopts a destructive method for achieving them $^{32}$.

Artificial Intelligence could be used in autonomous weapon technologies, which are automated for destruction. These AIs and weapons might accidently cause destructions at masses, if these are supposed under control of wrong hands ${ }^{33}$. Since humans are building AI from scratch on earth, it could be much easier to disable its ability at the time of crisis compared with the same problem on space. The main issue in space is to survive and build a long lasting living in peace not to create a new war with the human made technology. Regardless of the advantages of AI for astronauts, several ambiguous issues will be raised here:

Whether the usages of AI in robotic weapons and the wide application of nuclear power sources in space will lead to weaponization or military superiority of states and arms race in this arena? Are these technological developments conforming to basic principles of treaties of space law?

There is a further point, whether competent existing organizations such as: International Committee for Robot Arms Control (ICRAC) as a non-governmental organization focused on robotics technology to improve peaceful utilization of these technologies for serving humans and to regulate these technologies ${ }^{34}$ could be adequate? Is there any conflict with human rights law under increasing AI technology especially in weapons? What is the territorial scope of applicable law, the international space law or human rights law to make clear provisions of all these developments?

\section{Codification of Laws}

Different laws are made by international organizations for peaceful usage of the space. With the passage of time these anti weaponization and militarization of space laws are developed. But the main problem is that we have fragile and short-lived anti weaponization and militarization of space laws. It does not mean that we have no law at all. Some of the legislation, international and national available on the subject are as follow.

\subsection{International Legislation}

Now under international legislation we will see what kind of weapons might be placed in outer space and what are any legal limits on the scope of deployment, and what are other legal considerations. Now we would analyze the laws prevailing the weaponization of the outer space directly applicable globally.

\subsection{Outer Space Treaty (1967)}

The treaty concerning the principles prevailing various activities of nations in exploring and using outer space included with Moon and some other astronomic bodies (Outer Space Treaty) which was enforced on October 10, $1967^{35}$. The outer space treaty, considered as major foundation of guidance on the question of space weaponization and militarization.

\subsection{Legality of Weaponization}

This treaty doesn't consider weaponization of the Outer Space per se illegal ${ }^{36}$. But This Treaty does place a bar on weapons, which might be launched and measured their opportunity regarding placements.

\footnotetext{
${ }^{32}$ M. Tegmark, Benefits \& Risks of Artificial Intelligence. 2016, https://futureoflife.org/background/benefits-risks of-artificial-intelligence.

${ }^{33}$ B. Nogrady, The Real Risks of Artificial Intelligence. 10 November 2016, http://www.bbc.com/future/story/20161110-the-r eal-risks-of-artificial-intelligence,

${ }^{34}$ https://icrac.net/who

${ }^{35}$ The Outer Space Treaty, was opened for signature at Washington, London, and Moscow on January 27, 1967, and the Treaty entered into force on October 10, 1967.

${ }^{36}$ Nandasiri Jasentuliyana, International Space Law and the United Nations, (Kluwer Law International: Hague, 1999), 104
} 
This Treaty also contains an international consultation obligation that may apply on the event of weaponization $^{37}$.

\subsubsection{Type of Weapons}

According to the article-IV (1) of the treaty, there is prohibition on placement of nuclear-based weapons and Weapons of Mass Destruction (WMD) in the outer space, including celestial bodies ${ }^{38}$. But the article-IV (1) of the outer space treaty doesn't make explicit reference to the moon, instead stating that States Parties agreed not to place weapons on astronomic bodies, these type of weapons should be placed using some other forms. Some legal scholars are of the view that the failure of particularly the Moon creates a doubt on whether the nuclear based weapons and WMD deployment on the moon is prohibited. This ambiguity is prevailing over when considering true intent of contracting agencies, keeping in mind article-IV (1) in good faith within the circumstances of the treaty, and considering the object of the treaty. First, except for Article IV (1), the treaty considers the Moon and some other astronomic bodies, which indicates that the Moon is astronomic body. Therefore, only referring "astronomic bodies" does not leave out the moon. Second, the reservation of the moon exclusively for peaceful purposes implies no nuclear weapons or WMD may be placed on the moon, as such placement could not be completely for peaceful dedications ${ }^{39}$. Considering the language of Article IV (1) is derived exactly from General Assembly Resolution -1884 (XVIII) of United Nations, 1963. The resolution states the nations to abstain placement of nuclear-based weapons or any other type of mass destructive weapons, or fixing these types of weapons on astronomic bodies and installing these weapons in outer space in any form ${ }^{40}$. More likely, when the drafts included article-IV (1) of the outer space treaty, they didn't feel it necessary to change the wording of Resolution 1884, that's why explaining the failure of Article IV (1) to directly reference the moon. The article-IV (1) bans the position of the nuclear-based weapons and WMD "in orbit". This means that Inter Continental Ballistic Missiles (ICBMs), and further weapons that enter only in a sub-orbital route are not subject to Article IV (1). The United States Joint Chiefs of Staff have defined the term WMD as the weapons which are proficient in destruction of humans at greater level. These mass destructive weapons may be biological, nuclear, radiological, and chemical weapons, however, excluding various ways of transportation of these weapons ${ }^{41}$. States are free to install space weapons, except for prohibited nuclear-based weapons or WMD, subject to boundaries and prohibitions on the scope.

Scope: Placement in Earth orbit or the "outer void space" of prohibited weapon types is not allowed under the conditions of this treaty, these placements on Moon and other astronomic bodies is prohibited. Term "Outer Void Space" was first time used by Bin Cheng for the reason of clarifying article-IV in treaty of outer space and main purpose for provisions of that treaty. It means the void between celestial bodies. This distinguishes the common use of the phrase "Outer Space", which usually includes all celestial bodies, from a more refined and limited spatial reference, the "outer void space" ${ }^{\text {"42 }}$. A careful analysis of Article IV reveals different military activities on Moon and other astronomic bodies, comprising weapon placement, unless carried out completely for peaceful commitments are prohibited. The article-IV (2) clearly stops establishing military centers, fixing mechanisms for defenses, to test any kind of weapon and conducting, military operations on astronomic bodies ${ }^{43}$. But military recruits are allowed on the Moon and other astronomic places only for the sake of scientific research and any other peaceful purposes. Therefore, this treaty could forbid the settlements of weapons on the Moon and other space bodies on the reason that such a weapon is a military base, installation, or fortification.

\footnotetext{
${ }^{37}$ Outer Space Treaty, art. IX.

${ }^{38}$ Outer Space Treaty, art. IV.

${ }^{39}$ Outer Space Treaty, art. IV (2).

${ }^{40}$ General Assembly Resolution, Question of General and Complete Disarmament, UN GAOR, Res/1884 (XVIII), (1963).

${ }^{41}$ Quoting National Military Strategy to Combat Weapons, U.S. Chairman of the Joint Chiefs of Staff (February 13, 2006).

42 Bin Cheng, The 1967 Outer Space Treaty: Thirtieth Anniversary, (1998),156.

${ }^{43}$ Outer Space Treaty, supra note 9, art. IV (2).
} 


\subsection{Limited Test Ban Treaty (1963)}

This treaty prohibits all kinds of tests on the basis of nuclear-based weapons in outer space, under water, and in atmosphere, limited tests ban treaty was enforced on October 10, $1963^{44}$. Though not directly relating to outer space weaponization, but this Limited Test Ban Treaty puts some practical restrictions on the kind of space weapon that may be deployed.

Legality: This Treaty doesn't consider space Weaponization per se illegal if it is made for peaceful purposes.

Type: The Limited Test Ban Treaty does not directly put any restriction on any type of space weapon that might be installed ${ }^{45}$. But, this treaty prohibits detonation of the nuclear-based weapon or nuclear devices in the Earth's atmosphere or in the outer space. This puts a realistic curb on the type of outer space weapon that may be deployed. Though that Treaty doesn't restrict on the deployment of the nuclear-based weapon in the outer space.

Scope: This Treaty employs to the Outer Space and to the Earth's atmosphere. This Treaty is quiet as to whether the Moon and other astronomic bodies have been sheltered considering its provisions. Article 1(b) of the Treaty bars a nuclear detonation in any kind of other atmosphere causing dangerous remains placed outside the international boundaries of different countries where detonation have been organized. Even if one reads the term "Outer Space" barely to exclude the Moon and other astronomic bodies, article 1(b) includes outer space because this is not subjective to any nation or privilege of independence that should be measured an outer environment at regional authorities of various countries under whom control these detonations have been carried out.

\subsection{Convention on Environmental Modification Techniques (1978)}

This meeting conducted on prevention of Military or any other unfriendly use of the environment modification techniques established in October $5,1978^{46}$. Though this environmental convention doesn't straightly regulate the space weaponization, but this places some limitations on the type of weapons that may be used.

Legality: This Treaty doesn't deem space weaponization per se illegal is made for peaceful purposes.

Type: The environmental convention stops every member country to be involved in any military or other aggressive usage of Environmental Modification Techniques with extensive, enduring and acute consequences like massive destruction, harm or damage to any of country ${ }^{47}$. The phrase "Environmental Modification Techniques" means some methodologies, which change the deliberate exploitation of any natural procedure, masterpiece, the dynamics, and structure of earth, along with its hydrosphere, biota, outer space or lithosphere. The usage of space weaponization through the environment modifications technique with extensive, ongoing, and/ or acute consequence is banned. The placement of space weaponization able to causing environment modifications must be contemplated under the act in ruthless trust deteriorating the objectives and commitments of treaty.

\subsection{The United Nations Charter and Principles of International Law}

Every member state of UN is subject to the charter of United Nations ${ }^{48}$. Any exploration or usage of the Moon, outer space, and some other astronomic bodies, should done according to international law and must be in best relevance to maintain global peace and safety and to promote collaboration and

\footnotetext{
${ }^{44}$ Treaty Banning Nuclear Weapon Tests in the Atmosphere, in Outer Space and Under Water, signed at Moscow August 5, 1963.

${ }^{45}$ Treaty Banning Nuclear Weapon Tests in the Atmosphere, in Outer Space and Under Water, art (1).

${ }^{46}$ Convention on the Prohibition of Military or Any Other Hostile Use of Environmental Modification Techniques, signed in Geneva May 18, 1977.

${ }^{47}$ Convention on the Prohibition of Military or Any Other Hostile Use of Environmental Modification Techniques, signed in Geneva May 18, 1977, art (1).

48 "States Parties shall carry on activities in accordance with international law, including the Charter of the United Nations", art (3).
} 
consensus among nations ${ }^{49}$. The settlement of the space weapon may highlight issues with regard to threats caused by using force and policies for preventative self-protection.

Legality: The usage of space weaponization is not per se banned under the UN Charter and under principles of the international law, if not deployed against provisions of the charter.

Type: No State has placed a nuclear weapon of WMD in Earth orbit or outer space. An argument holds the ground that the prohibition against the launching of nuclear weapons or WMDs in Earth orbit has received the status of ordinary international law resulting consistent state exercises \& opinion juries.

Scope: With accordance to the UN Charter and the principles of the International Law must be applied to all member countries of the world. The article-2 (4) of the UN charter should require all member countries to abstain in relations internationally from the dangers and uses of military against regional honesty and other administrative independence of the countries, or in other means of variability with the UN purposes. It is possible that some States as violating article 2(4) of the UN Charter may consider the launching of a space weapon. Then, depending on the location, type, and capability of a used space weapon, with the perceived intent of use, the UN Charter and international law may be violated. In reply to the placement of a space weapon, which is viewed like disruption of the International Law and the United Nations charter, States may turn to article 5196 of the UN Charter as legal authority to hold actions of self-protection against the State that launched the space weapon.

\subsection{The Registration Convention of 1974}

The Convention on the Registration of the Objects Launched into the Outer Space was enforced on September 15, $1976^{50}$. This Registration Convention actually does not legalize the weaponization of outer space, but does create an obligation to register space objects if launched in Earth's orbit and outside of it. The launching of the space weapon in earth's orbit or outside of it triggers the obligation under the Registration Convention. Theoretically, deployment and the employment may happen almost at the same time. Problem arises when term "launch" is used outside the context of this Convention. Outside this Convention, the term launch is used with reference to the firing of weapons. Generally, the launch of a missile or other weapon from the Earth's surface follows a sub-orbital route to another terrestrial location. However, it is possible for a space weapon to be fired from Earth into an Earth orbital trajectory. If the space weapon is fired and not only deployed for later use, the Convention may apply. However, this seems noticeably ridiculous and may be deemed outside the range of the Convention.

Legality: The article-II of Registration Convention requires registration of any space item propelled in Earth's orbit or outside of it by launching country ${ }^{51}$. the Convention somewhat defined the space item or object as component parts of the space objects and its launching medium and their parts. A Space weapons system, either as a sovereign object or as an included system with a larger object, should come within the space objects definition if that space weapon launched. The Convention does not give the definition of "launched". Therefore, it is ambiguous whether the Convention applies to launches conducted from Earth only or whether this also applies to launches conducted on astronomic bodies or/and from the outer void space. If a space weapon is launched, then the country launching it must registered the launching mechanism of the object, which it shall maintain ${ }^{52}$. If it is launched by more States than one, article II (2) permits for the joint launching States to decide about the object to be registered by state or country. The article-VII requires intercontinental, international organizations, like space agency of Europe, in Registration Convention, if that organization declared reception of obligations and rights prescribed there under. There is no prohibiting for space objects launched for military purposes.

Type: This convention applies to the objects to be launched in Earth's orbit or outside of it.

Scope: This convention evidently applies to earthly-based launches. Whether or not the scope of the Convention applies to non-terrestrial launches is ambiguous. In theory, a space weapon made in the

\footnotetext{
${ }^{49}$ See Ibid.

${ }^{50}$ Convention on the Registration of Objects Launched into Outer Space, entered into force September 15, 1976.

${ }^{51}$ Ibid, art. II (1).

${ }^{52} \mathrm{Ibid}$, art. II (1).
} 
outer void space and/or on any other astronomic bodies should not be measured as having been propelled, therefore it is not subjective to register fulfilling requirements under this convention.

\subsection{National Legislation}

National legislation means the domestic laws developed by different nations on space law. The national internal legal system with indispensable substances is the legislation and development of legal theories by common law where the constitution allows such to happen. The debate and process of legislation and its enactment, the elucidation by judges of their decisions on that legislation or on common law, and debate of publicists all help to elucidate the law, point out to its popular development and identify flaw. More practical space law matures within the diverse municipal legal systems of the world, and mainly those of states that are space-active. One obvious area of municipal law that can deal with questions of space is Contract. A contract entails the rights and obligations reached between the parties, subject to any conditions imposed by the existing legal system on grounds of public policy.

However, the 'law of contract' is not worldwide: different municipal systems differ in detail. It is possible that those are agreeing on space-relevant contracts and settling of all types of space disputes are budding concepts and particular 'space' meanings for well-known terms of which we are right now unaware. In recent years a practice has adopted whereby parties, whether states, state agencies, companies or individuals, do not conclude a general contract but enter into Memoranda of Understanding. There is no unanimous definition of what a Memorandum of Understanding is being a matter of la. However, definitions are different by different intellectuals. A MOU is more general than a 'gentleman's agreement' but 'lesser than a contract'. It may, not necessarily, precede a contract. Actually there are different ways to make national legislation for militarization and weaponization of space. Only a few countries made some national laws relevant to the weaponization of space like USA and USSR.

\section{Recommendations}

It is need of hour to halt this trend of weaponization and militarization of space by clarifying some essential issues regarding air space and authority of a nation to launch activities in that air space. In this respect following are important policy implications;

- First, it is proposed to draft more binding agreements and establishing exclusive organizations other than inter-governmental organizations beyond the cooperation of UN organizations to deal with challenges related to the governing law on space with the specific authority on limiting activities of private entities and settlement of disputes will help to secure the future of space and its resources for next generation.

- Second, the International community first of all should try to come on one page for definition of airspace and be agree thereon.

- It is envisaged to Establish an international legal regime that effectively protects and also a separate international entity acting as a legislative assembly with uniform mechanisms and rules to protect the mutual benefits of global communities and the mankind.

- United Nations should play a key role in legislation process with regard to outer space and should bring the global community on one page. The global principles pertinent to manmade actions in outer space must be interpreted at the UN platform.

- Space International Law is considered as division of International Public Law. Therefore, all actions taken in the outer space should be assumed in agreement with essential rules of the international law, especially that are comprised in charter of the UN. This notion is protected in accordance to article-III of the outer space treaty, 1967.

- All of the countries reserves then right to accessibility, exploration and usage of the outer space. None of the state desires to gain authority to perform various actions in space or could be differentiated in contradiction to their economic prosperity. That rule is articulated in article-1 in the treaty of outer space.

- There should be consensus on controlled and uncontrolled airspace. Although already it is generally considered that the organized airspace endures, whenever it seems prerequisite that air 
traffic control has some positive implications on the crafts that fly in outer space and unorganized airspace is that one, where air traffic control doesn't apply any administrative authority, though it might exploit any recommended approach. It is imperative for all stakeholders to admit it.

- Airspace might be divided into further divisions, zones, areas considering the prohibited areas for suck kind of actions relating to weaponization and militarization of it or complete prohibition of such activities.

- $\quad$ Presently the neutral airspace as given in san remo manual, composed of airspace above water and lands of neutral countries but we should try to specifically demark the neutral airspace to conduct activities in those areas.

- According to International Law, the idea of state's sovereignty airspace resembles with marine definition of regional water considered as 12 marine miles $(22.2 \mathrm{Km})$ away from country's coast. Then airspace which is not in any state's regional boundary is measured intercontinental, corresponding to "high Sea" in marine law but international community should come to a definite notion a sovereign airspace of a nation. Same as maritime territorial of water notion.

- First clear areas of controlled airspace, uncontrolled airspace and sovereign airspace then we should discuss that how a country for his self-defense can put a weapons into airspace but under such international restrictions we do not disturb the balance of peace in this world. Peaceful purposes considering improvement of technology and reduce of militarization possibility inconformity with human rights law should be clarified ${ }^{53}$.

- The rapid development in space technologies has introduced the commercialization of space activities is most emerging trend in $21^{\text {st }}$ century. These trends have been especially observable in manufacturing filed and operationalization of telecommunications satellite and launch of these business, and no law prevails on it, it's very dangerous and there is no check and balance and it can be purchased by any terrorist organization and it can rack and ruin at vast level.

- For international community there is a dire need to constitute more space law regulation, which should be in a straight line relevant to military conflicts and their power exercises in outer space. Being part of such principles, each and everything should be having a clear definitions and conceptual clearance is needed to be formulated for all the ideas similar to "Space Weapon" and "Peaceful Purpose" and "military Use" what is militarization of space, weaponization of space etc.

- Furthermore, there is also need for the international community to explain the primary issue of "where space Begin" which must be clearly undertaken to tackle opinions about the existence of the outer space as a region which relates to the zones of member country for their national safely measures.

- In addition, there is need of establishing International Treaty to represent contemporary intercontinental routine law to stop placement of main conventional weapon in the space. We should also incorporate in such treaty sections that include, the reporting \& evaluation, public assessment and to pass any confronting conflict to the international court. Means precedents of IJC should be the part and parcel of international treaty.

- At an international level adoption of binding agreements or non-binding provisions aiming to avoid militarization and possible crimes through using Artificial Intelligence and also determining state responsibilities for damages would be practical. Although, there are several judicial bodies on the international level which could adjudicate cases involving the use of robotic weapons in warfare like International Court of Justice (ICJ) International Criminal Court (ICC) and International Human Rights Bodies, but collaboration between them under the UN jurisdiction would be more beneficial.

\footnotetext{
${ }^{53}$ N. Melzer, Human rights implications of the usage of drones and unmanned robots in warfare. Brussels: European Parliament, 2013. Directorate-General for External Policies of the Union, EXPO/B/DROI/2012/12.
} 


\section{Conclusion}

World has changed so the laws must be changed or modify. The prevailing International laws against weaponization and militarization into the space are insufficient to curb the trend of militarization and weaponization of space. Actually the great space super powers are the responsible for weaponization and militarization and their quest to defeat each other tried to make the space another battle ground. The rapid development in the field of space technologies including the progress in space weapons system has departed legitimation slow down. Keeping in view all these circumstances, there is dire need of new strict laws or modifications in the existing space law regime and disarmament in outer space. international community should find approaches to find out new opportunities and mitigate challenges opposing the weaponization and militarization of the space. Thus, there is a dire need for an international space law regime to maintain the safety of outer space in the greater interest of humankind. Additionally, this paper suggests an intergovernmental international space authority empowered to consolidate clear-cut definite rules on the inspection and evaluation of state protection, allocation of responsibility, enforcement of sanctions, and awards as a panacea for all space issues.

\section{References}

1. Cheng, B. The 1967 Outer Space Treaty: Thirtieth Anniversary, (1998),156.

2. Convention on the Prohibition of Military or Any Other Hostile Use of Environmental Modification Techniques, signed in Geneva May 18, 1977.

3. Convention on International Civil Aviation, Chicago, 1944.

4. Convention on the Registration of Objects Launched into Outer Space, entered into force September 15, 1976.

5. E. Korovin, La Conquéte de la Stratosphere et le Droit International, (Rev. Gen. de Droit Int.,1934) ,41.

6. General Assembly Resolution, Question of General and Complete Disarmament, UN GAOR, Res/1884 (XVIII), (1963)

7. H. York, Nuclear Deterrence and the Military Uses of Space, (F. Long, D. Hafner and J. Boutwell, eds., Weapons and Space, 1999), 17.

8. Henry L. S. "Is the Weaponization of Space Inevitable"?

9. Jasentuliyana, N. International Space Law and the United Nations, (Kluwer Law International: Hague, 1999), 104.

10. Jessup, Cf. P.C. The Reality of International Law, (1940), 18.

11. Karen, E. "United States public delegate to the 63rd session UNGA. delivered in the debate on outer space (disarmament aspects) of the general assembly's first committee" in: Arms Control Update, U.S. Delegation to the Conference on Disarmament, Geneva, October 20, 2008

12. Ley, W. "Rockets, Men and Missiles in Space" (New York: Signet, 1969), 77.

13. Larsen, P.B. Issues Relating to the Civilian and Military Uses of GNSS, (2001), 17.

14. Michael Sirak, Air force leadership: Chinese ASAT marked turning point: space No longer sanctuary, Defense Dail. (February 12, 2007).

15. Michael O' Hanlon, Technology Change and the Future Warfare, Manas Publications, New Delhi, 2005, p. 1.

16. Michael O' Hanlon, UNCOPUOS $59^{\text {th }}$ session Vienna, 8-17 June 2016, Report of the LSC $55^{\text {th }}$ session, held in Vienna from 4-15 April 2016.

17. Melzer, N. "Human rights implications of the usage of drones and unmanned robots in warfare". Brussels: European Parliament, 2013.

18. Michael Sirak, Air force leadership: Chinese ASAT marked turning point: space No longer sanctuary, Defense Dail. (February 12, 2007).

19. Nogrady, B. The Real Risks of Artificial Intelligence. 10 November 2016,

20. Podvig, P. Russian Military Space Capabilities, (2002), 24.

21. Robert A. R. "Armed Conflict on the Final Frontier: The Law of War in Space" (2000), 554.

22. Sandra E. Defense official: Trump is serious about creating a space force, Space News (15 March, 2018).

23. Samson, V. CDI Analysis: Shooting Down USA 193, World Security Institute, February 27, 2008.

24. Smith, R.A., Correspondence: Man and his Mark, (Paris: Presses Universities de France, 1949) ,55.

25. The Outer Space Treaty, was opened for signature at Washington, London, and Moscow on January 27, 1967, and the Treaty entered into force on October 10, 1967. 
26. Treaty Banning Nuclear Weapon Tests in the Atmosphere, in Outer Space and Under Water, signed at Moscow August 5, 1963.

27. The Outer Space Treaty, was opened for signature at Washington, London, and Moscow on January 27, 1967, and the Treaty entered into force on October 10, 1967.

28. Technology Change and the Future Warfare, Manas Publications, New Delhi, 2005, p. 1.

29. Tegmark, M. Benefits \& Risks of Artificial Intelligence. 2016, https://futureoflife.org/background/benefits-risks -of-artificial-intelligence.

30. U.S. Chairman of the Joint Chiefs of Staff, Feb. 13, 2006, Quoting National Military Strategy to Combat Weapons.

31. UNCOPUOS $59^{\text {th }}$ session Vienna, 8-17 June 2016, Report of the LSC $55^{\text {th }}$ session, held in Vienna from 4-15 April 2016.

32. Woods, M. "Satellites Provide Vital Reconnaissance, Communications to War Effort" (University of Cologne press, 2005), 44.

33. Wolf, J. "US Eyes Space as Possible Battleground" (Paris: Presses Universities de France, 2005), 47.

34. Weeden, Brian. 2007 Chinese Anti-Satellite Test Fact Sheet," Secure World Foundation. 